\title{
Transaction Process in the Implementation of Rural Budget Allocation Program in Kutai Kartanegara Regency
}

\author{
Syahrani
}

\begin{abstract}
The objective of the research is to analyze and describe the transaction process in drafting the program of Rural Budget Allocation in Kutai Kartanegara Regency, the forms of transaction which are formulated, the influence of the people power and interest who are involved in the transaction, and the actors who are involved.

The research was carried out by using qualitative method. The data collection was done through deep interviews, documentation and field observations by using interactive analysis model of Miles and Huberman.

The research results showed that the process of transaction was occured since pre Development Plan Meeting and at the time of Rural Development Plan Meeting were implemented. The forms of transaction were done through bargaining and persuasive. The actors who attend the meeting were representative but the motivation, hoping, and interest orientation were still dominated by personal interest, and the quality of them were also still low. There was still any utilization of power and individual interest used by the village headmans. The actors who were involved in the process of transaction came from various representative and different amount. The amount and variety of representatives more less at pre Development Plan Meeting than at the implementation time. The actors who involved in the process of transaction were categorized as formal and non-formal groups. The mechanism of drafting Rural Budget Allocation program not suitable with the Regulation of Minister of Home Affairs No. 66, 2007 concerning Rural Development Plan.

In order to obtain the rank of program priority for society interest and may protected from self-interest, it shoud be performed scoring on a number of issues based on specific criteria so that the problem rank and value adding on a number of alternative problem solution based on criteria could be achieved.
\end{abstract}

\section{Introduction}

The policy of Rural Budget Allocation is a manifestation of the village right fulfillment in order to create village autonomy, so it may follow the growth and development of the village itself based on diversity, participation, pure autonomy, democratization and society empowerment. (Mahfouz, 2009, 10-22).

The means of society participation may be as forum of community which is funcioned as an interaction space between the citizens and the government of village in managing and implementing Rural Budget Allocation.

The availability of community space is needed in order to make transaction process between the residents and the local government concerning the programs of Rural Budget Allocation that will be implemented.

The available of society forum creates the community awareness to plan and implement a program of development and as aspiration facility for society. The participation space in the activities of rural budget allocation including the participation in discussing the commitee of rural budget allocation, forum to formulate rural budget allocation, forum to socialize allocating the rural budget allocation, forum to discuss the mechanism of determining rural budget allocarion in rural budget.

The characteristics and specification of implementation for Rural Budget Allocation program is the implemetation of the policy using botton up approach (Parson, 1997: 463 in Putra, 2003: 85) which requires the active participation of society since from planning, implementation, evaluation until maintenance (principles of Rural Budget AllocationGovernment Regulation No. 27, 2005). The available of transaction process which resulted negotiation is characteristic of botton up approach, Pulzl and Treib (in Fischer, 2009; 90) Bottom up critiques view local bureaucrats as the main actors in policy delivery and conceive of implementation as negotiation process within networks of implementers.

One of the theory used Botton Up approach is Smith theory. Smith (1983:202-205) thought the policy implementation as social change :

"In order to develop a model of process, it is essential to view the policy process from the point of view of social and political change. Governmental policies are designed to induce changes in society.

Futhermore Smith (1983:197) said :

"Policy implementation is seen as a tension generating force in society. Tensions are generated between and within four components of the implementing process : idealized policy, implementing organization, 
target group, and environmental faktors. The tensions result in transaction patterns which may or may not match the expectations of outcome of the policy formulators. The transaction patterns may become crystallized into institutions. Both the transaction patterns and the institutions may generate tensions which, by feedback to the policymakers and implementors, may support or reject further implementation of the policy".

According to Max Weber (1968 in Hidayat, 2007: 11) transacation is necessary action to establish, maintain and or change social relations. Futhermore, Furubotn and Richter (2000 in Hidayat, 2007: 11), the transaction is a transfer of goods, services, information, knowledge, etc. from one place (the community) to the other (community) or transfer of goods from the manufacturer to consumen, or removal goods from one individual to another. So the transaction occurs when there are two or more people (institutions) to exchange goods and services or the other and expect to receive in return. Similarly, social exchange theory was originally based on a principle of elementary economic transaction where the people supply goods or services and in return hope to obtain goods or services desired (Poloma, 1994: 52). In exchange according to Homans (in Poloma, 1994: 65) there are reward, cost and profit which affecting each other.

Phenomenon that indicates the process is not carried out transactions in the preparation of Rural Budget Allocation program, stated by Syahruddin, Acting Head of Finance Management and Rural Asset, Agency for Community Empowerment of Kutai Kartanegara, in one of the newspapers in East Kalimantan " Tribune Newspaper" (East Kalimantan Tribune Newspapers, Monday, May 11, 2009) states:

"in order that the rural bureaucrats do not use the services of brokers when drafting the Rural Funds Allocation. If caught, Bapemas will not process the documents of Rural Budget Allocationwhich they report. "............. Furthermore, Syahruddin also said the lack of transparency in some of the village headmans." We saw there was a village headman who is not open to put them together. There may be a project that he had hidden. Thus, in its formulation does not involve Village Consultative Board and the villagers, "he said. (Kaltim Tribune newspaper, Monday, May 11, 2009)".

This is due to the interests, power and strategies of the actors involved. Grindle (in Nawawi, 2009; 144) said power, interest, and strategy used by the actors involved in the implementation of the policy needs to be taken into account, because it affects the success of the implementation.

Based on the research problems above, the writer doing a research with the title "Transaction Process in Implementaion of Village Funds Allocation Program in Kutai Kartanegara Regency".

The study objective was to describe, analyze and interpret :

1. Transaction process in drafting rural budget allocation program (ADD program ) in Kutai Regency,

2. Actors involved,

3. Transaction forms are formed, and

4. Role of power and interest of actor involved in in drafting rural budget allocation program (ADD Program )

\section{Methodology}

The reasearch method used is a qualitative approach. This approach is used in order to obtain deep and comprehensive descriptions concerning the transaction process in the implementation of Rural Budget Allocation program in Kutai Kartanegara Regency. The research location was done in the area of Kutai Kartanegara Regency which covering the subdistricts of zona hulu, central and beach coastal area.

To obtain the data needed, the researcher used three techniques of data collection, namely

- in-depth interview : conduct in-depth interviews with several key informants such as the head office of Bapemas, the village chief, the head of the LPM, heads and members of BPD and Chairman RT.

- Documentation: the collection of secondary data such as reports, archives, research and the like.

- Participant observation; make observations on various social events or situations that relate to the problem or research focus

The data was analyzed using interactive models as proposed by Miles and Huberman (1992), this model consists of three components, namely data reduction analysis, presentation of data and conclusion.

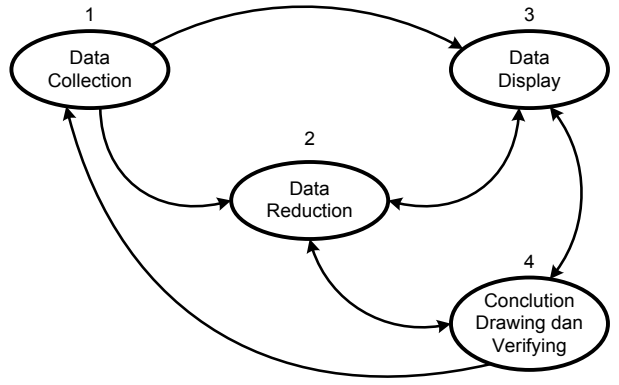

Sumber: Miles dan Huberman ( $1992 ; 20)$ 
Data reduction: The data collected is reduced and summarized in a way chosen subject matters, which are not relevant discarded, focused on the things that are important. Then sifting through data based on unit concepts, themes, and certain categories that will provide a sharper picture of the observations and facilitate researchers to seek additional data if needed

Presentation of data: All data presented in the form of narrative text, charts and relationship to allow for the temporary conclusion

Conclusion: Interpretation of the data was conducted to obtain a deeper meaning and wider on the results of the research being done, by noting regularities, patterns, explanations, possible configurations, causal flow and propositions.

The data was analyzed repeatedly and continuously as interactive models in the time before, during and after data collection in order to obtain a conclusion about how to process the transaction , transaction forms , actors involved and how the influence of power and interests of actors ruling in the transaction process

\section{Results}

Transactions occur when two or more people making social relationship exchanging, so that transfer imformation, knowledge or goods from one party to the other, from one actor to another could be seen in the process of drafting Rural Budget Allocationprogram. In this process, there are two stages were occured, namely in pra Development Plan Meeting (Pra-Musrenbang) and the time of Rural Development Plan Meeting (Musrenbang).

\section{a). Transaction Process in Drafting Rural Budget AllocationProgram}

In the implementation of drafting Rural Budget Allocation program, transaction process was done in two stages. First, since before the implementation of development plan meeting in village level, the transaction process occurs between neighbohood association and informal leaders in village level (1 village consists of 4 up to 7 neighbohood associations). In this process they seek to propose programs that will be carried in rural development plan meeting (Musrenbang). The existence of pra development plan meeting (Pramusrenbang) is participative approach in planning for obtaining aspiration from society in the village level, Number of actors involved is small. Meanwhile in the rural development plan meeting (Musrenbang), the number of actors involved are more bigger because it was covered by various representives from all sectors in rural area.

At the pre development plan meeting, transaction process relating to the discussion of the village portrait, condition of institutional village and season condition namely the environmental potential and problems of each region within the village neighborhood level, as well as the discussion of finding solutions to the problem. The process of transactions begined with discussion of the issues faced and available village potential led by the chairman or a member of LPM, with informal leaders and neighbohood associations. In this process, sharing of experience and argumentation and conflict were occurred.

In the level of pre development plan meeting, the results obtained in the form of proposed programs that will be taken into rural development plan meeting including the amount of the proposed program of each neighbohood associations or informal leaders. Therefore, at the time of rural development plan meeting, the actors just discuss programs that have been proposed to provide an explanation and clarification regarding potential, problem solutions and priority program. This process is conducted in order to avoid a long discussion and debate at the time of rural development plan meeting.

Refering the regulation of the Minister of Home Affairs No. 66, 2007 concerning Rural Development Plan, mechanism of village development plan is a mechanism of system model as mentioned by David Easton (in Indianhono, 2009; 40). He said that a policy can not possibly exist in a vacuum chamber, the policy is a result of interaction with the environment. In this system, there are five approaches instrumental in the decision making process a policy, that is input, process/transformation, output, feedback, and the environment itself. Input is demands and support of interest groups (fishermen, farmers and others) including environmental surrounding stress such as and village potential problems, village institutions and calendar of season, meanwhile process is done at the time of development plan meeting and pre development plan meeting to determine the rank and group of problems, to review problem-solving, and to determine rank of the action, while the ouput is programs of Rural Bdget Allocation listed in the five-yearly Medium Term Development Plan of Rural and annual Village Development.

\section{b). Actors of Transaction}

More than 70\% motive, objectives, expectations and interests of actors in developing Rural Budget Allocation program emphasis on infrastructure program, because by the infrastructure activities will provide work opportunities and increase the incomes.

The quality of actor, especially heads of neighbohood association and informal leaders generally have educational level in elementary school. Most of the informal leaders and heads of the neighbohood association 
have low education level caused by the recruitment system which are more focused on the appointment of elders and respected/feared. Meanwhile, village officials have education level in average is high school that is approximately $45.060 \%$, followed by elementary school is approximately $26.88 \%$ and junior high school is approximately $22.23 \%$, while pre graduate level only $4.25 \%$.

Table 18: Level of education of the village government of Kab. Kutai Kartanegara

\begin{tabular}{|c|c|c|c|c|c|c|c|c|c|c|c|}
\hline \multirow[b]{2}{*}{ No } & \multirow[b]{2}{*}{$\begin{array}{l}\text { Level of } \\
\text { Education }\end{array}$} & \multirow[b]{2}{*}{$\begin{array}{l}\text { head } \\
\text { village }\end{array}$} & \multirow[b]{2}{*}{$\begin{array}{c}\text { secretar } \\
\mathrm{y}\end{array}$} & \multicolumn{6}{|c|}{ The head of affairs } & \multirow[b]{2}{*}{ Total } & \multirow[b]{2}{*}{$\%$} \\
\hline & & & & $\begin{array}{l}\text { Rural } \\
\text { gover } \\
\text { nment }\end{array}$ & $\begin{array}{c}\text { Devel } \\
\text { opmen } \\
\mathrm{t}\end{array}$ & $\begin{array}{c}\text { Gener } \\
\text { al }\end{array}$ & $\begin{array}{c}\text { Welfa } \\
\text { re }\end{array}$ & $\begin{array}{c}\text { Securi } \\
\text { ty }\end{array}$ & $\begin{array}{c}\text { Treasur } \\
\text { er }\end{array}$ & & \\
\hline 1 & Bechelor & 16 & 8 & 6 & 5 & 3 & 2 & 1 & 1 & 43 & 4,25 \\
\hline 2 & Diploma & 4 & 5 & 4 & 2 & 1 & 0 & 0 & 0 & 16 & 1,58 \\
\hline 3 & High school & 104 & 100 & 68 & 70 & 70 & 20 & 16 & 8 & 456 & 45,06 \\
\hline 4 & Yunior & 33 & 35 & 44 & 44 & 33 & 15 & 11 & 10 & 225 & 22,23 \\
\hline 5 & primary school & 28 & 37 & 63 & 59 & 62 & 8 & 13 & 2 & 272 & 26,88 \\
\hline & Total & 185 & 185 & 185 & 180 & 169 & 45 & 41 & 21 & 1012 & 100 \\
\hline
\end{tabular}

Sourcer: Bapemas Kukar 2013

Meanwhile, training for the actors regarding planning program is adequate. As long as 2010 year, it is found 7 programs of development plan training, among others: Strengthening Information of Village and Rural Profiles, program of recording Rural and village entrance, government meeting of village, developing management of participative development, improving LPM capacity, improving neighbohood associations capacity, guiding and socializing rural and village development plan meeting as well as recording rural and village entrance program. In 2011, the programs founded are preparation of integration of village development plan, implementation of village development meeting, activity of information strengthening of village and rural profiles, and activity for operator technical guidance of village and rural profiles.

The number of actors involved in the time of pre development plan meeting is little which consisted of heads of neighbohood association, informal leaders, religious leaders, youth leaders and heads of rural. That is caused by the scope of meeting only cover the backwoods area. Meanwhile number of the actors involved in the development plan meeting is much larger because it includes village areas. The participants of development plan meeting usually are attended by Agency for Rural Development, Institute of Rural Development, Family Communication Forum, neighbohood association forum, heads of rural, village headmans and apparatus, traditional leaders, subdistrict apparatus, district apparatus, and cross-sectoral representative such as school, fisherman and farmers group.

\section{c). Forms of Transaction}

The transaction may occur in various forms, such as bargaining, persuasion or coercion (Anderson, 1979; 76). Based on observations and interviews can be conclused that the transaction process both during the pre development plan meeting and at the time of development plan meeting, there was a bargaining happened among the actors who involved in meeting, caused by the available of mutual adjustment among themselves on some of the programs proposing instead of getting benefits for other program.

In the process of this transaction rarely will be also happened persuasive process, namely if any conflict happened among the actors in proposing a program, the actors are affecting each other to convince their opponents that their proposed program acceptable and assure them that the proposed program better, right, useful and can solve the problem as well as needed.

\section{d). Role of Power and Interest of Actor}

With regard to the use of power and interests, there were founded abuse of powers done by some of village headmans by doing proposals in Rural Development Plan Meeting, meanwhile the programs are never propsed in pre Rural Development Plan Meeting. This is caused by the village headmans impose proposed program based on the private interests without through the mechanism of pre Rural Development Plan Meeting.

\section{Discussion}

\section{a). Transaction Process in Drafting Rural Budget Allocation Program}

By looking at the field Musrenbangdes mechanisms, mechanisms of rural development programming plans are not all walking mechanism as set forth in Permendagri No. 66 of 2007 on the Village Development Planning,. In Permendagri the input component (in output) is assessing the state of the village that has been done at pramusrenbang. At the time of assessment of the state of the actors bring the issues and the potential on the basis of observations around the scope of the RT / hamlet alone and in the process (conversion) of the actors did not perform grouping and assignment problems on peringkatan problem, the actors fail to directly perform consultation to discuss solutions to the determination of the action problems. In consultation nevertheless they 
are not based on the criteria contained in Permendagri, such criteria: the problem many people have felt, very severe, common and available potential to solve and prevent an increase in revenue. But the actors do not do giving scores to these criteria, the actors only by frustrated consultation to determine whether the problem is urgent and sometimes if fail consultation / discussion obstacles (Conflict), the actors do a review of spaciousness to determine the urgency of the problem or not to be solved.

Later in the program to determine the order of priority, the actors discussed enough alone, not based on ratings actions based on scoring criteria Permendagri No. 66 of 2007 concerning Rural Development Planning as criteria: 1). The proposal meets the needs of the people, 2). Support increased income and 3). There is potential support.

So the actors are not delivering value in determining program priorities, they are quite discussed to determine the proposed programs. This is in line with the findings of the evaluation of "Participatory Planning in Kutai regency" which states: "planning mechanisms tend to be a ritual, a kind of formal ritunitas, do not touch the substance and lose their absolute meaning (Bapeda Kukar, 2009: 7).

Minor propositions are proposed: "If the actors are able to identify problems, potential and needs of residents and assessment (scoring) on the problem and the proposed program then processes the transaction in the preparation of the ADD program to describe the public interest"

\section{b). Actors of Transaction}

Policy actors are those who always and be involved in any decision-making process either as a formulator and pressure groups constantly active and proactive in making the interaction and interrelationships in the context of public policy analysis (Howlett and Ramesh 1995 in Silalahi, 1999). Thus the relevant actors are actors and policy makers who interact and perform interrelated in any policy process / program. Policy actors have motives, interests, expectations, orientation, goals, and objectives who articulate and fight for prefensi policy or in response to the policies of other actors prefensi, Harmon (1969 in Prasetyo, 2010; 3) said that the public interest is a consequence which appear in the formulation of public policy determined by the orientation and interests of the actors involved, both government actors (administrators) and community actors differentiated by interest groups that exist within the community. Poloma (1994: 52) says the social exchange theory was originally based on the elementary principles of economic transactions: the supply of goods or services and in return hope to obtain goods or services desired. Enterprises actors in the fight for the program, which is in line with the theory of exchange, they expect to sacrifice goods and services that benefit the programs they earn (Homans in Poloma 1994, 65). In this process a lot of wasted time and energy they did all cultivated with profit and loss calculations. Therefore the behavior of the transaction is always oriented goals is to get the program (Blau in Poloma 1994, 83). Clearer Grindle (1980) says: policy implementation rather than dealing with the issue of translating policy objectives into action programs or routine administrative procedure, but would also involve ............... determination of who gets what in a society. Robbin $(1995 ; 277)$ said: The dicision maker is Likely let him or her own interests influence decision making.

Based on the findings of the data, Rural Budget Allocation program for more than $70 \%$ emphasis on infrastructure programs, because the infrastructure activities will provide employment opportunities, they can do, and increase their incomes. This indicates the motive, the hope still characterize the orientation of a personal interest in the Rural Budget Allocation program.

Therefore, in the process of preparation did giving scores on a number of issues and programs based on certain criteria allowing private interests coloring in the program.

Judging from the data level of education and skills of actor-actor as well as the impact of the transaction remains low politics that led to the replacement of the head of village empowerment efefktivenya not given. Subarsono $(2006,7)$ states the quality of the policy will be influenced by the quality of the actors involved in the policymaking process. The quality will be determined by level of education, competence and field, The experience of work and moral integrity.

The quantity of actors transaction at pre-musrembang smaller number with a diversity of actors involved is also less diverse than the time in which the actors involved Musrenbangdes more numerous and diverse.

Actors involved in the transaction of Rural Budget Allocation programming from external and internal bureaucratic red tape. James Laster and Joseph Stewart (in Winarno, 2002.84) said the groups involved in the policy process is the formal and non-formal groups. Formal groups such as government administrative agencies which include the executive, legislative and yudicatif. While non-formal group consisting of: 1) The interest groups (interest group) 2) the political parties and 3). Individual citizen. According to public opinion Stewart actors in program implementation of Rural Budget Allocation are the messengers of formal and non-formal. Here are the various actors involved in the transaction 
Transaction Process in the Implementation of Rural Budget Allocation Program in ....

Table 1: the various actors in the transaction

\begin{tabular}{|l|l|}
\hline Various actors & \\
\hline Informal actors & $\begin{array}{l}\text { RT chairman, chairman of the village, religious leaders, traditional leaders, representatives of women's } \\
\text { groups, youth youth clubs, community organizations, groups of fishermen / farmers, school committees, } \\
\text { employers and others }\end{array}$ \\
\hline Formal actor & $\begin{array}{l}\text { The village head, the chairman and members of the village consultative bodies (BPD), subdistrict, district } \\
\text { officials, principals, heads of health centers, agency officials in the village or district, NGOs and others }\end{array}$ \\
\hline
\end{tabular}

Source: Results of study, 2013

This is in line with Wibowo's research that states actors involved in the formulation of policy is divided into two: the official actors (structural / executive) and the role of non structural (Wibowo, 8, 2011)

Minor propositions are proposed: "If the actors involved are representative, qualified, and have motive, purpose and orientation of actors in the public interest then the resulting program will be qualified"

\section{c). Forms of Transaction}

Form of transactions in drafting rural budget allocation program is bergaining due to the process of negotiation, give and take and compromise. Transaction processing occurs because two or more actors or groups of actors who each have the authority and positions but can make adjustments (sharing) that is expected to wake up in the policy-making system, due to this condition leads to the step of the negotiation. After negotiations between actors occur in different positions between the actors, the principle of mutual giving and receiving and then coloring the decision-making process. Ultimately this process will lead to the compromistic / agreements in which each actor to each other to make adjustments to the concept or idea of any other actor that could decide the policy od Rural Budget Allocation program.Anderson ( 1979; 79) said bargaining as a process in which two or more persons in positions of power or authority adjust their at lease partially inconsistent goals in order to formulate a course of action that acceptable but not necessasrily ideal to the participants

Later in the transaction process is formed also persuasive, because the actors attempt to convince other actors. In seeking support, the actors usually try to convince other actors to show that his opinion completely acceptable, useful and solve problems, and according to the needs and potential are forms of persuasion activities undertaken actor, therefore relates to emotional persuasion, the can touch the feelings of the actors that other actors may accept.Anderson $(1979 ; 80-18)$ said : persuasion is attempts to convince others of the correctness of value of one'sposition and therebay cause them to adapt it as their own.

Figure 1: Relationship atmosphere nevertheless consultation with the transaction form

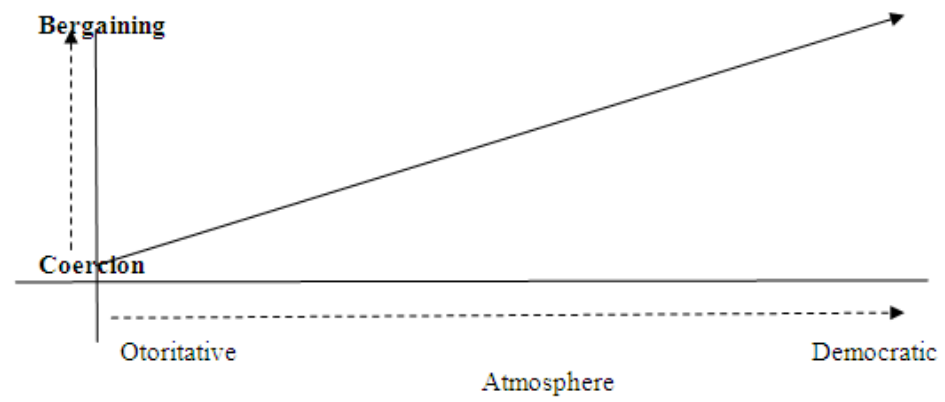

Source: Results of the study (2013)

According to Prasetyo $(2011 ; 16)$ bergaining occurs at the stage of problem solving and agenda setting.

Minor propositions are proposed: "bargaining transaction will be formed if the transaction is democratic atmosphere"

\section{d). Role of Power and Actor Interest}

Power is a relationship in which a person or group of people can determine the action of another person or group, so may suitable with the purpose of the first party. According to Certo $(1994,242)$ said Authority is the right to perform or command. Martin Lodge (dalam Fischer, 2009; 281) authority is defined as the use of legal or official power to "determine" in the "allowing" and "forbidding' sense. Meanwhile, the sense of power can be interpreted as coercion. Mills (in Silalahi, 1999, 95) suggests the power as domination is ability to execute a willingness, although others oppose. Therefore, the concept of power consists of two sides, namely positive and negative sides. In reality, there are actors who have different powers more than any other actors, so it makes the process of public policy more domineted by orientation and interests of actors and another actors.

Futhermore, the public interest is the interest or needs which regarding the public. The interest is related to the benefits for the people, and can be enjoyed together. It can be distinguished clearly between the 
interests of personal and a handful or a group of people. Public interests is basically a combination of the orientation of the actors involved. Quality orientation of each of the actors in the policy formulation process is very having an effect on the quality of the orientation between actors in the process of implementation of public policy (Prasetyo, 2011, 21)

Power and interests of the actors can influence the success of the Rural Budget Allocation, Grindle (in Nawawi, 2009; 144) said power, interests and strategies (power, interest, and strategy of the actors involved) used by the actors involved in the implementation of the policy should be calculeted, because it may affects the success of the implementation.

The use of power by village headmans to force personal interest in the Rural Budget Allocation program called as individualistic public interests. Harmon (1969 in Prasetyo, 2010; 5) models of public interest are divided into several variations, among others: public interest as individualistic describes public interest as reflection or dominated by the interests of powerful individuals. Unitaristic public interest is if the public interest is a form of pluralism of the public interest in an entity.

Of minor propositions above it can be arranged major proposition as follows: "If the actors have the quality, motive, purpose, public interest orientation and transaction processing is done in a democratic atmosphere that the resulting program will be qualified"

\section{Conclusion}

- The process of transaction in drafting Rural Budget Allocation program takes place in two stages, namely at the pre development plan meeting and at the time of rural development plan meeting. The process of transactions have taken place in the form of displacement imformasi, knowledge and experience between actors. The transaction occured in two forms namely bargaining and persuasive.

- The actors who attend the meeting were representative but the motivation, hoping, and interest orientation were still dominated by personal interest, and the quality of them were also still low.

- The actors who were involved in the process of transaction came from various representative and different amount. The amount and variety of representatives more less at pre Development Plan Meeting than at the implementation time. The actors who involved in the process of transaction were categorized as formal and non-formal groups.

- The mechanism of drafting Rural Budget Allocation program not suitable with the Regulation of Minister of Home Affairs No. 66, 2007 concerning Rural Development Plan.

\section{Suggestion}

In order to obtain the rank of program priority for society interest and may protected from self-interest, it shoud be performed scoring on a number of issues based on specific criteria so that the problem rank and value adding on a number of alternative problem solution based on criteria could be achieved.

\section{Tex Books:}

\section{References}

[1]. Certo, Samuel C, 1994. Modern Management, Englewood Cliffs, New Jersey

[2]. Fischer, Frank dkk, 2007., Handbook of Public Policy Analisys, CRC Press London

[3]. Hidayat, Aceng, 2007. Pengantar Ekonomi Kelembagaan, IPB, Bogor

[4]. Indiahono, Dwiyanto., 2009; Kebijakan Publik Berbasis Dynamic Policy Analisys, Gava Media, Yogyakarta.

[5]. James E Anderson,.., 1967, Public Policy Making New York, Rinehart and Wonston $2^{\text {nd }}$.

[6]. Miles, Matthew B and a Michael Huberman, 1992, Analisa Data Kualitatif, sage Publication Inc Inggeris

[7]. Nawawi, Ismail, 2009. Public Policy, Analisis, Strategi Advokasi Teori dan Praktek, PMN, Surabaya

[8]. Parsons, Wayne, 2008, Public Policy, Fajar Interpratama Offset, Jakarta

[9]. Poloma, Margaret M, 1994, Sosiologi Komtemporer, PT. Raja Grafindo Persada, Jakarta

[10]. Robbin, Stephen S, 1997, Organizational Behavior, Prentice-Hall International Editions, USA

[11]. Smith, Thomas R, 1983., The Policy Implementation Process, Elservier Scientific Publishing Company, Amsterdam, Printed In Scotland

[12]. Subarsono, 2008; Analisis Kebijakan Publik, Cetakan Ke-2, Pustaka Pelajar, Jakarta

[13]. Sumartono, Hetifah Sj, 2008. Inovasi, Partisipasi Dan Good Governance, Yayasan Obor Indonesia, Jakarta.

[14]. Winarno, Budi, Ph.D, 1989, Teori Kebijaksanaan Publik, Pusat Antar Universitas Studi Sosial, Universitas Gajah Mada, Yogyakarta.

\section{Journals and Research Results}

[15]. Mahfudz, 2009, 10-22, Dampak ADD, Jurnal Organisasi dan Manajemen, Volume 5, Nomor 1, Undip

[16]. Prasetyo, Budi, 2010, Orientasi Aktor dalam perumusan kebijakan Publik, Dept. Ilmu Politik Fisip, Universitas Airlanggar, Jurnal Masyarakat Kebudayaan dan Politik, Volume 2, 115-130.

[17]. Wibowo, Udik Budi, 2011, Intensitas Peran Actor Kebijakan Publik dan Kekuatan Politis dalam Perumusan Kebijakan Sertfikasi Pendidikan, Jurnal Penelitian Ilmu Pendidikan Volume 4 Nomor 1. 